\title{
GOAT MANURE FERTILIZATION AND IRRIGATION ON PRODUCTION COMPONENTS OF SUNFLOWER ${ }^{1}$
}

\author{
FRANCISCA ROBEVANIA MEDEIROS BORGES ${ }^{2 *}$, FRANCISCO MARCUS LIMA BEZERRA ${ }^{3}$, ALBANISE \\ BARBOSA MARINHO ${ }^{2}$, ELÍSIA GOMES RAMOS ${ }^{2}$, JILSON DE NAZARÉ JOSÉ ADRIANO ${ }^{4}$
}

\begin{abstract}
Sunflower can be an economically viable crop in the Northeast region of Brazil depending on the use of appropriate irrigation and fertilization managements. The objective of this work was to evaluate production components of sunflower plants (Helianthus annuus L.) of the BRS-324 cultivar subjected to different organic fertilizer rates (goat manure) and irrigation water depths in two crop cycles (November 2014 to February 2015; and August to November 2015). The experiment was conducted in a randomized block design with a split-split-plot arrangement, consisting of five organic fertilizer rates (OFR) $(0,300,600,900$, and $1.200 \mathrm{~mL} \mathrm{plant}^{-1}$ week $\left.^{-1}\right)$ and five irrigation water depths (IWD) $(33 ; 66 ; 100 ; 133$, and $166 \%$ of the class A tank evaporation), with three blocks. The highest achene yield $\left(1,220.78 \mathrm{~kg} \mathrm{ha}^{-1}\right)$ in the first cycle was found using OFR of 1,200 mL plant ${ }^{-1}$ week $^{-1}$ and IWD of 134.9\% (524.9 mm); and the highest yield $\left(882.07 \mathrm{~kg} \mathrm{ha}^{-1}\right)$ in the second crop cycle was found using the highest OFR combined with IWD of $166 \%(843.0 \mathrm{~mm})$. The use of goat manure as organic fertilizer had no effect on the sunflower oil content; however, this variable was affected by the irrigation water depths used. Protein content was higher in the second crop cycle (14\%) when using IWD of $100 \%$ and OFR of $536 \mathrm{~mL} \mathrm{plant}^{-1}$ week $^{-1}$.
\end{abstract}

Keywords: Helianthus annuus L. Organic fertilizer. Irrigation management. Class A tank. Yield.

\section{POTENCIAL PRODUTIVO DO GIRASSOL SOB DOSES DE BIOFERTILIZANTE CAPRINO E LÂMINAS DE IRRIGAÇÃO}

\begin{abstract}
RESUMO - O girassol, do ponto de vista econômico, apresenta viabilidade para a região Nordeste, desde que adotado o manejo adequado de aplicação de água e adubação. Baseado nisso, o presente trabalho teve como objetivo avaliar o potencial produtivo do girassol, variedade BRS 324, sob doses de biofertilizante caprino e lâminas de irrigação, em dois ciclos. $\mathrm{O}$ experimento foi instalado em blocos casualizados no esquema de parcelas subsubdivididas, onde foram testadas a aplicação de cinco doses de biofertilizante caprino $(0,300$, 600, 900 e $1.200 \mathrm{~mL}_{\text {planta }}{ }^{-1}$ semana $\left.^{-1}\right)$ e cinco lâminas de irrigação $(33 ; 66 ; 100 ; 133$ e $166 \%$ da evaporação medida no tanque Classe "A"), em dois ciclos de cultivo, com três blocos. O $1^{\circ}$ ciclo foi conduzido entre novembro/2014 e fevereiro/2015 e o $2^{\circ}$ ciclo de agosto/2015 a novembro/2015. A maior produtividade da cultura foi obtida no $1^{\circ}$ ciclo $\left(1.220,78 \mathrm{~kg} \mathrm{ha}^{-1}\right)$ na dose de biofertilizante $1.200 \mathrm{~mL}$ planta $^{-1}$ semana $^{-1}$ combinada à lâmina $134,9 \%$ da ECA $(524,9 \mathrm{~mm})$. No $2^{\circ}$ ciclo, a máxima produtividade de $882,07 \mathrm{~kg} \mathrm{ha}^{-1}$ foi proporcionada com a maior dose de biofertilizante e a lâmina de irrigação de $166 \%$ da ECA $(843,0 \mathrm{~mm})$. A aplicação do biofertilizante caprino não alterou o teor de óleo de girassol, todavia, evidencia-se incrementos para esta variável em resposta às lâminas de irrigação. Os teores de proteína se mostram superiores no $2^{\circ}$ ciclo de cultivo (14\%) respondendo de forma efetiva a combinação da lâmina média de $100 \%$ da ECA com a dose $536 \mathrm{~mL}_{\text {planta }}{ }^{-1}$ semana $^{-1}$ de biofertilizante caprino.
\end{abstract}

Palavras-chave: Helianthus annuus L. Adubação orgânica. Manejo da irrigação. Tanque Classe A. Produtividade.

\footnotetext{
${ }^{*}$ Corresponding author

${ }^{1}$ Received for publication in 08/02/2017; accepted in 12/04/2018.

Paper extracted from the doctoral thesis of the first author.

${ }^{2}$ Institute of Rural Development, Universidade da Integração Internacional da Lusofonia Afro-Brasileira, Redenção, CE, Brazil; robevaniab@gmail.com - ORCID: 0000-0003-3897-2975, albanise@unilab.edu.br - ORCID: 0000-0002-8006-2011, lisyramos16@hotmail.com - ORCID: 0000-0002-6459-2004.

${ }^{3}$ Department of Agricultural Engineering, Universidade Federal do Ceará, Fortaleza, CE, Brazil; mbezerra@ufc.br - ORCID: 0000-00029334-8297.

${ }^{4}$ Center for Agricultural, Environmental and Biological Sciences, Universidade Federal do Recôncavo da Bahia, Cruz das Almas, BA, Brazil; agronaza@aluno.unilab.edu.br - ORCID: 0000-0002-3837-5313.
} 


\section{INTRODUCTION}

The BRS-324 sunflower (Helianthus annuus L.) cultivar was developed by the Brazilian Agricultural Research Corporation and partners. This cultivar has crop cycles between 80 and 100 days, seeds (achenes) with high oil content (45\% to $49 \%)$, 1,000 -achene weight of 50 to $65 \mathrm{~g}$, and average achene yield of $1,500 \mathrm{~kg} \mathrm{ha}^{-1}$ in the South, Central West, and Northeast regions of Brazil (CARVALHO et al., 2013).

According to Soares and Galbiati (2012), residues from animal production are potential organic fertilizers for agriculture, which can total or partially reduce the use of synthetic fertilizers, thus, reducing production costs, maximizing productivity (SOUSA et al., 2013), and decreasing water consumption (FREIRE et al., 2011).

Liquid organic fertilizers have better distribution of nutrients to the plants than other forms of organic fertilizers, making them easily available to plants (OLIVEIRA et al., 2014). Goat manure has desirable characteristics to produce soil organic fertilizers. According to Malavolta et al. (2002), goat manure has a better structure (more solid and much less aqueous) than bovine or swine manures, generating better aeration and faster fermentation; thus, it can be used in agriculture after a shorter decomposition period.

Agriculture in the Brazilian Northeast is very dependent on climatic conditions due to the low and irregular rainfalls in this region (SANTOS et al., 2009). Considering that plant development is significantly affected by water availability, irrigation practices are needed for plant production in this region.

Evaluations of irrigation water depths have been used to determine water requirements of crops under specific growing conditions (SIMÕES et al., 2016). Low water availability reduces plant production, and excess water limits soil aeration, affects absorption of nutrients, increases disease risks, and contributes to nutrient leaching (VIANA et al., 2012).
Studies have analyzed isolated effects of irrigation and fertilization that may limit crop production, and the interaction between them. Lima et al. (2013) evaluated sesame plants grown under different irrigation water depths, and with and without bovine organic fertilizer, and found increased seed yield because of the interaction between the irrigation and fertilizer. Sousa et al. (2014) found higher plant height of sesame plants when using irrigation water depth of $181.5 \mathrm{~mm}$ and bovine manure.

In this context, the objective of this work was to evaluate production components of sunflower plants of the BRS-324 cultivar subjected to different organic fertilizer rates (goat manure) and irrigation water depths in two crop cycles, under the edaphoclimatic conditions of Maciço de Baturité, state of Ceará, Brazil.

\section{MATERIAL AND METHODS}

The experiment was conducted at the experimental farm of the University for International Integration of the Afro-Brazilian Lusophony, in Redenção, Ceará, Brazil (04¹5'55"S; 3879'37"W; and altitude of $240 \mathrm{~m}$ ). Rainfall in this region has irregular distribution, is concentrated between January and April, and presents total annual depths of 380 to $760 \mathrm{~mm}$.

Sunflower seeds of the BRS-324 cultivar were seeded in 39.5-liter pots with spacing of $0.5 \mathrm{~m}$ x 0.7 , simulating a plant density of 28.570 plants ha ${ }^{1}$. The pots contained a 0.05 -meter gravel layer at the bottom for draining excess water, and soil of the region and sand $(2: 1)$.

Samples of the substrate were collected before applying the treatments and sent to the Soil and Water Laboratory of the Federal University of Ceará (UFC) for chemical analysis (Table 1), which was performed according to the methodology described in Embrapa (2011). The same substrates were used for the respective treatments of the second crop cycle.

Table 1. Chemical attributes of the soil and sand (2:1) substrate used for the sowing of sunflower seeds.

\begin{tabular}{|c|c|c|c|c|c|c|c|}
\hline \multicolumn{8}{|c|}{ Chemical attributes } \\
\hline $\mathrm{mg} \mathrm{dm}{ }^{3}$ & \multicolumn{7}{|c|}{$\mathrm{mmol}_{\mathrm{c}} \mathrm{kg}^{-1}$} \\
\hline $\mathrm{P}$ & $\mathrm{K}^{+}$ & $\mathrm{Ca}^{2+}$ & $\mathrm{Mg}^{2+}$ & $\mathrm{Na}^{+}$ & $\mathrm{H}^{+}+\mathrm{Al}^{3+}$ & SB & CEC \\
\hline \multirow[t]{2}{*}{60} & 1.1 & 20.0 & 10.0 & 0.80 & 3.30 & 32 & 35 \\
\hline & \multicolumn{2}{|c|}{------g kg ${ }^{-1}----$} & \multicolumn{2}{|c|}{--------\%o------ } & $\mathrm{dS} \mathrm{m} \mathrm{m}^{-1}$ & \multirow{2}{*}{\multicolumn{2}{|c|}{$\mathrm{C} / \mathrm{N}$}} \\
\hline $\mathrm{pH}$ & $\mathrm{C}$ & $\mathrm{OM}$ & BS & ESS & $\mathrm{EC}$ & & \\
\hline 7.3 & 1.98 & 3.41 & 91 & 2 & 0.24 & & 10 \\
\hline
\end{tabular}

$\mathrm{SB}=$ sum of bases; $\mathrm{CEC}=$ cation exchange capacity $\mathrm{BS}=$ base saturation; $\mathrm{ESS}=$ exchangeable sodium saturation; $\mathrm{EC}=$ electrical conductivity. Source: Soil Laboratory of the UFC/FUNCEME. 
The experiment was conducted in a randomized block design with a split-split-plot arrangement, consisting of five rates of organic fertilizer (goat manure) $(0 ; 300 ; 600 ; 900$, and 1,200 $\mathrm{mL}$ plant $^{-1}$ week $\left.^{-1}\right)$ and five irrigation water depths
$(33 ; 66 ; 100 ; 133$, and $166 \%$ of the class A tank evaporation), with three blocks, in two crop cycles (November 2014 to February 2015, and August to November 2015). The climatic conditions during each crop cycle are shown in Table 2.

Table 2. Average air temperature, class A tank evaporation (CAE), and total rainfall (TR) during the experiment.

\begin{tabular}{|c|c|c|c|c|c|c|}
\hline First cycle & $\begin{array}{c}\text { Number of } \\
\text { days }\end{array}$ & $\begin{array}{c}\text { Temperature } \\
\left({ }^{\circ} \mathrm{C}\right)\end{array}$ & $\begin{array}{c}\text { CAE } \\
\left(\mathrm{mm} \mathrm{month}^{-1}\right)\end{array}$ & $\begin{array}{c}\mathrm{CAE} \\
\left(\mathrm{mm} \mathrm{day}^{-1}\right)\end{array}$ & $\begin{array}{c}\text { TR } \\
\left(\mathrm{mm} \mathrm{month}^{-1}\right)\end{array}$ & $\begin{array}{c}\text { TR } \\
\left(\mathrm{mm} \mathrm{day}^{-1}\right)\end{array}$ \\
\hline November & 12 & 25.82 & 38.80 & 3.23 & 7.90 & 0.66 \\
\hline December & 31 & 26.60 & 131.20 & 4.23 & 26.90 & 0.87 \\
\hline January & 31 & 26.50 & 33.60 & 1.08 & 113.20 & 3.65 \\
\hline February & 19 & 26.20 & 18.30 & 0.96 & 76.80 & 4.04 \\
\hline Total/Mean & 93 & 26.28 & 221.90 & 2.38 & 224.80 & 2.31 \\
\hline Second cycle & $\begin{array}{c}\text { Number of } \\
\text { days }\end{array}$ & $\begin{array}{c}\text { Temperature } \\
\left({ }^{\circ} \mathrm{C}\right)\end{array}$ & $\begin{array}{c}\text { CAE } \\
\left(\mathrm{mm} \mathrm{month}^{-1}\right)\end{array}$ & $\begin{array}{c}\mathrm{CAE} \\
\left(\mathrm{mm} \mathrm{day}^{-1}\right)\end{array}$ & $\begin{array}{c}\text { TR } \\
\left(\mathrm{mm} \mathrm{month}^{-1}\right)\end{array}$ & $\begin{array}{c}\text { TR } \\
\left(\mathrm{mm} \mathrm{day}^{-1}\right)\end{array}$ \\
\hline August & 24 & 28.08 & 132.00 & 5.50 & 0.00 & 0.00 \\
\hline September & 30 & 27.83 & 151.30 & 5.04 & 3.63 & 0.12 \\
\hline October & 31 & 27.44 & 201.60 & 6.50 & 3.38 & 0.11 \\
\hline November & 03 & 27.86 & 16.70 & 5.57 & 0.00 & 0.00 \\
\hline Total/Mean & 88 & 27.80 & 501.60 & 5.65 & 7.01 & 0.06 \\
\hline
\end{tabular}

Source: Piroás Experimental Farm - UNILAB.

The organic fertilizer was applied once a week, starting at 15 days after the germination (DAG). It was prepared by aerobic fermentation of a compost containing fresh goat manure, wood ashes, and water (100:10:220) (DIAS, 2014) for 30 days. This compost was placed in a 500-liter plastic box and manually aerated twice a day for one hour to accelerate the decomposition process.

The organic fertilizer was doubly sieved using $50 \%$ and $80 \%$ mesh sieves to be applied through a pressurized system. The material retained in the sieves was discarded.

The organic fertilizer was applied using drippers with adjustable flow (GA-2, Agrojet ${ }^{\circledR}$ ), which was adapted to work at maximum flow $(40 \mathrm{~L}$ $\mathrm{h}^{-1}$ ) to avoid clogging. The fertigation system had one lateral line per plant row and one emitter per pot.

Samples of the organic fertilizer were sent to the Soil and Water Laboratory of the UFC for chemical analysis (Table 3 ).

Table 3. Chemical attributes of the liquid organic fertilizer (goat manure) used for sunflower plants in two crop cycles.

\begin{tabular}{ccccccccc}
\hline \multicolumn{7}{c}{ Chemical attributes - First cycle } \\
\hline \multicolumn{7}{c}{$\mathrm{g} \mathrm{kg}^{-1}$} \\
$\mathrm{~N}$ & $\mathrm{P}$ & $\mathrm{K}$ & $\mathrm{Ca}^{2+}$ & $\mathrm{Mg}^{2+}$ & $\mathrm{S}$ & $\mathrm{Zn}$ & $\mathrm{Cu}$ \\
0.4 & 0.1 & 3.6 & 1.3 & 1.6 & - & 2.5 & 0.8 & 4.6 \\
\hline \multicolumn{10}{c}{ Chemical attributes - Second cycle } \\
\hline $\mathrm{N}$ & $\mathrm{P}$ & $\mathrm{K}$ & $\mathrm{Ca}^{2+}$ & $\mathrm{Mg} \mathrm{kg}^{-1}$ & $\mathrm{~S}$ & $\mathrm{Zn}$ & $\mathrm{Cu}$ \\
0.1 & 0.36 & 1.6 & 0.29 & 0.37 & - & 6.91 & 0.01 & 6.34 \\
\hline
\end{tabular}

Source: Soil and Water Laboratory of the UFC.

The irrigation system consisted of selfcompensating drippers installed in a lateral line, independently from the fertigation system, and set according to the different treatments (water depths) - the emitters were combined to result in flow rates of $2,4,6,8$, and $10 \mathrm{~L} \mathrm{~h}^{-1}$, representing 33, 66, 100, 133 , and $166 \% \mathrm{~mm}$ of the class A tank evaporation (CAE), respectively, using a working pressure of $196 \mathrm{kPa}$. A class A tank and a rainfall gauge were installed near the experimental area to collect evaporation and rainfall data, respectively. The irrigation time was calculated using Equation 1,

$T i=\frac{F * C A E * A v}{E i * q g}$

wherein $T i$ is the irrigation time (hours); $F$ is the adjustment factor of the water depth to be applied as a function of the $\operatorname{CAE}(0.33,0.66,1.0,1.33$, and 1.66); $C A E$ is the class A tank evaporation $\left(\mathrm{mm} \mathrm{day}{ }^{-1}\right) ; A v$ is the pot area $\left(0.08 \mathrm{~m}^{2}\right) ; E i$ is the 
irrigation efficiency (0.88), dimensionless; and $q_{g}$ is the dripper flow $\left(\mathrm{L} \mathrm{h}^{-1}\right)$.

The water depths were calculated based on rainfall indexes of the last 24 hours, i.e., when the rainfall exceeded the $\mathrm{CAE}$, the irrigation was suspended; however, when the rainfall was not sufficient, the irrigation complemented the evaporation.

The variables evaluated were 1,000-achene weight, achene yield, water use efficiency for achene production, achene oil content and yield, and achene protein content and yield.

The weight of 1,000-achene was determined according to the Rules for Seed Analysis (BRASIL, 1992). Achene yield was determined by weighing the achenes and calculate the average yield of achenes per hectare $\left(\mathrm{kg} \mathrm{ha}^{-1}\right)$ considering a plant density of 28,570 plants $\mathrm{ha}^{-1}$. Achene oil and protein contents were determined according to the methodology proposed by Silva et al. (2004), and their yields ( $\mathrm{kg}$ $\mathrm{ha}^{-1}$ ) were estimated considering the achene yield. Water use efficiency (WUE) for achene production $\left(\mathrm{kg} \mathrm{ha}^{-1} \mathrm{~mm}^{-1}\right)$ was determined by the achene yield to water depth ratio of each crop cycle.

The data were subjected to ANOVA at 5\% significance for the F test, using the ASSISTAT 7.7 beta software. When the two quantitative factors were significant, the data were subjected to simple regression analysis, or response surface (for significant interaction between factors). When the triple interaction (crop cycle $\times$ organic fertilizer rate $\times$ irrigation water depth) was significant, the organic fertilizer rate $\times$ irrigation water depth interaction was subjected to statistical breakdown within each crop cycle, since the crop cycles were included to promote high-consistent results. Graphs, equations, and best combinations of treatments were generated in the Table Curve 3D program.

\section{RESULTS AND DISCUSSION}

The total irrigation water depth applied was calculated based on the rainfall occurred in the first $(224.80 \mathrm{~mm})$ and second $(7.01 \mathrm{~mm})$ crop cycles. Thus, the total irrigation of the treatments of each crop cycle, considering the CAE $(33 \%, 66 \%, 100 \%$, $133 \%$, and $166 \%$ ), were, respectively, 298.78 , $372.73,446.68,520.63$, and $594.58 \mathrm{~mm}$ in the first, and $174.20,341.40,508.60,675.80$, and $843 \mathrm{~mm}$ in the second crop cycle. Excess rainfall occurred in some periods of the first crop cycle, changing the irrigation water depths established for the experiment.

The interaction between crop cycles, organic fertilizer rates, and irrigation water depths significantly affected (triple interaction) the 1,000achene weight (1000AW), achene yield, water use efficiency (WUE) for achene production, and oil and protein yields (Table 4). Oil content was affected by the interaction between crop cycles and irrigation water depths; and protein content was affected by the interactions between crop cycles and water depths, and between organic fertilizer rates and water depths.

Table 4. Analysis of variance of 1,000-achene weight (1000AW), achene yield (AY), achene oil content (AOC), achene protein content (APC), achene oil yield (AOY), achene protein yield (APY), and water use efficiency (WUE) for achene production of sunflower plants.

\begin{tabular}{ccccccccc}
\hline \multirow{2}{*}{ Source of variation } & DF & \multicolumn{7}{c}{ Mean square } \\
\cline { 2 - 8 } & & $1000 \mathrm{AW}$ & AY & WUE & AOC & APC & AOY & APY \\
\hline Block & 2 & $37.5^{\text {ns }}$ & $15822^{\text {ns }}$ & $0.07^{\text {ns }}$ & $65.0^{\text {ns }}$ & $0.02^{\text {ns }}$ & $13488^{\text {ns }}$ & $287^{\text {ns }}$ \\
Crop cycle (CC) & 1 & $3739^{* *}$ & $7691721^{* *}$ & $48.0^{* *}$ & $0.8^{\text {ns }}$ & $687.4^{* *}$ & $1624417^{* *}$ & $23624^{* *}$ \\
Residue (CC) & 1 & 31.1 & 849 & 0.004 & 69.2 & 0.60 & 6729 & 34 \\
OFR & 4 & $1323^{* *}$ & $922020^{* *}$ & $3.85^{* *}$ & $82.7^{\text {ns }}$ & $8.56^{*}$ & $177364^{* *}$ & $12769^{* *}$ \\
CC*OFR & 4 & $291.8^{* *}$ & $22803^{\text {ns }}$ & $0.26^{*}$ & $94.1^{\text {ns }}$ & $2.17^{\text {ns }}$ & $4580^{\text {ns }}$ & $918^{*}$ \\
Residue (OFR) & 16 & 57.2 & 13572 & 0.07 & 31.7 & 2.07 & 6828 & 299 \\
IWD & 4 & $931.2^{* *}$ & $742690^{* *}$ & $1.89^{* *}$ & $56.0^{*}$ & $11.53^{* *}$ & $166528^{* *}$ & $12697^{* *}$ \\
CC*IWD & 4 & $43.5^{\text {ns }}$ & $49297^{* *}$ & $0.29^{* *}$ & $113.0^{* *}$ & $6.08^{* *}$ & $28017^{* *}$ & $510^{* *}$ \\
OFR*IWD & 16 & $84.4^{* *}$ & $73984^{* *}$ & $0.29^{* *}$ & $32.5^{\text {ns }}$ & $5.52^{* *}$ & $19317^{* *}$ & $752^{* *}$ \\
CC*OFR*IWD & 16 & $91.8^{* *}$ & $29149^{* *}$ & $0.13^{* *}$ & $25.3^{\text {ns }}$ & $2.00^{\text {ns }}$ & $8863^{* *}$ & $445^{* *}$ \\
Residue (IWD) & 80 & 29.9 & 4416 & 0.02 & 20.4 & 1.14 & 2633 & 125 \\
Total & 149 & - & - & - & - & - & - & - \\
\hline CV - CC (\%) & - & 11.89 & 4.25 & 3.94 & 17.90 & 6.65 & 25.67 & 7.66 \\
CV - OFR (\%) & - & 16.12 & 17.00 & 17.38 & 12.12 & 12.09 & 25.86 & 22.58 \\
CV - IWD (\%) & - & 11.67 & 9.70 & 10.20 & 9.73 & 8.99 & 16.06 & 14.59 \\
\hline
\end{tabular}

$\mathrm{OFR}=$ organic fertilizer (goat manure) rates; IWD = irrigation water depths; $\mathrm{DF}=$ degree of freedom; $\mathrm{CV}=$ coefficient of variation; $*=$ significant at $1 \% ; * *=$ significant at $5 \%$; and $\mathrm{ns}=$ not significant 
The statistical breakdown of the triple interaction for $1000 \mathrm{AW}$ is presented through the response surfaces and their respective mathematical models for each crop cycle (Figure 1). According to estimates, the combination of the organic fertilizer rate (OFR) of $923.7 \mathrm{~mL}_{\text {plant }}{ }^{-1}$ week $^{-1}$ with the irrigation water depth (IWD) of $166 \%$ of the CAE $(594.6 \mathrm{~mm})$ in the first crop cycle promoted the highest 1000AW (63.0 g). The highest 1000AW estimated for the second crop cycle was $56.7 \mathrm{~g}$ using the OFR of $1,200 \mathrm{~mL}$ plant $^{-1}$ week $^{-1}$ and IWD of $166 \%(843.0 \mathrm{~mm})$. These results are in accordance with technical specifications for the BRS-324 sunflower cultivar (50 to $65 \mathrm{~g}$ ) (CARVALHO et al., 2013).

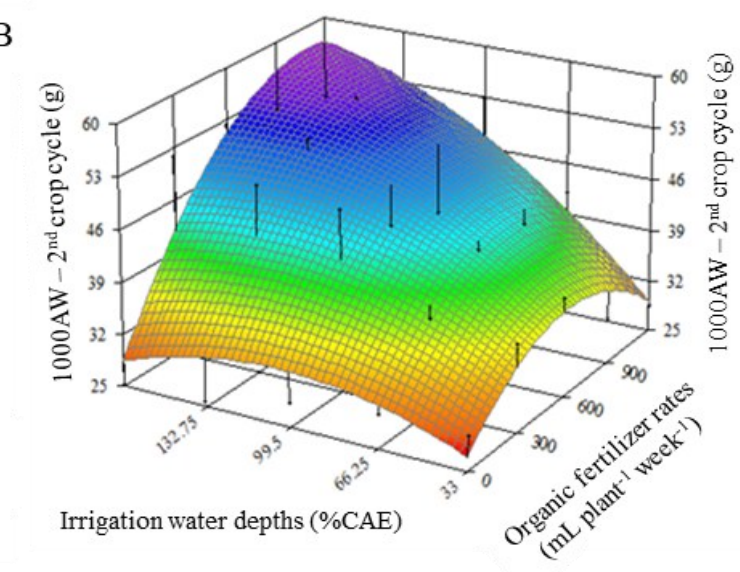

Irrigation water depths $(\% \mathrm{CAE})$

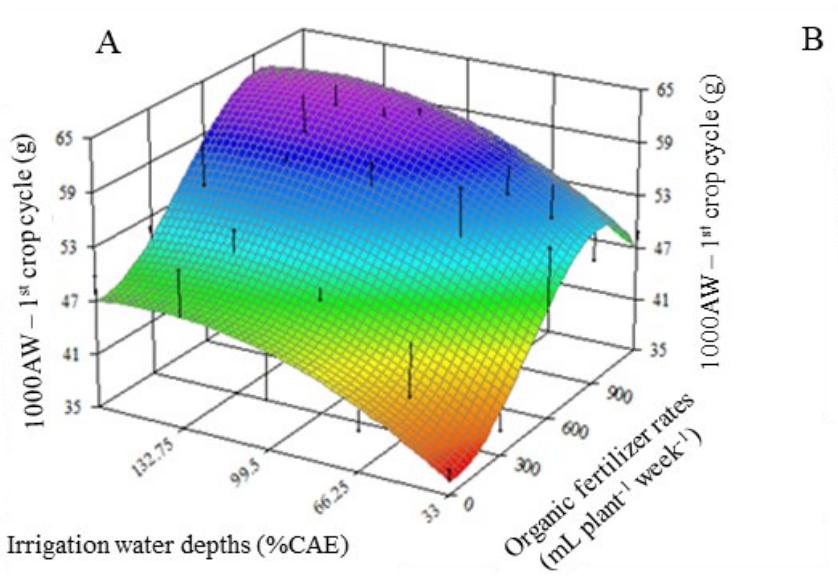

$(\mathrm{OFR})^{2}-0.00000004511 * *(\mathrm{OFR})^{3}-0.26200(\mathrm{IWD})+$ $\mathrm{R}^{2}=0.77$

$1000 \mathrm{AW}_{2}{ }^{\text {nd }}{ }_{\text {crop cycle }}=20.45573 *+0.02523403 * *(\mathrm{OFR})+0.2260449(\mathrm{IWD})-0.00002388798 *(\mathrm{OFR})^{2}-0.0010690267(\mathrm{IWD})^{2}$ $+0.00016221833 * *(\mathrm{OFR})(\mathrm{IWD}) \quad \mathrm{R}^{2}=0.77$

Figure 1. Response surface for 1,000-achene weight (1000AW) in the first (A) and second (B) crop cycles of sunflower as a function of organic fertilizer rates (OFR) and irrigation water depths (IWD).

Similarly, Lobo et al. (2013) found a positive effect of organic fertilizer (sewage sludge) on $1000 \mathrm{AW}$ of sunflower plants, resulting in an average of $72.5 \mathrm{~g}$, and maximum of $79.5 \mathrm{~g}$.

The higher estimated 1000AW was found with the highest IWD applied-594.58 mm (first crop cycle) and $843 \mathrm{~mm}$ (second crop cycle). The excess rainfall (greater than the CAE) in the first cycle probably resulted in no water restriction in the achene filling period, when there is a strong competition for assimilates between the achenes, resulting in a greater $1000 \mathrm{AW}$ and achene production. Silva et al. (2011); Araújo et al. (2012) also found higher 1000AW in sunflower plants when using the highest IWD $(533.7 \mathrm{~mm}$ and $807.1 \mathrm{~mm}$, respectively).

In general, sunflower achene yield responded positively to increasing OFR and IWD, denoting the importance of the combination between these two factors to obtain higher yields. According to the mathematical model, an achene yield of $1220.78 \mathrm{~kg}$ $\mathrm{ha}^{-1}$ could be achieved using the highest OFR $(1,200$ $\mathrm{mL}$ plant $^{-1}$ week $\left.^{-1}\right)$ combined with an IWD of $134.9 \%(524.9 \mathrm{~mm})$ in the first cycle. The highest achene yield $\left(882.07 \mathrm{~kg} \mathrm{ha}^{-1}\right)$ in the second cycle was also found using the highest OFR when combined with IWD of $166 \%(843.0 \mathrm{~mm})$ (Figure 2).

Therefore, the estimated achene yield for the recommended plant density for the cultivar $(40,000$ plants $\mathrm{ha}^{-1}$ ) would be $1,709.18 \mathrm{~kg} \mathrm{ha}^{-1}$ in the first, and $1,234.96 \mathrm{~kg} \mathrm{ha}^{-1}$ in the second crop cycle. These results would be similar to that found by Carvalho et al. (2013) $\left(1,500 \mathrm{~kg} \mathrm{ha}^{-1}\right)$. 


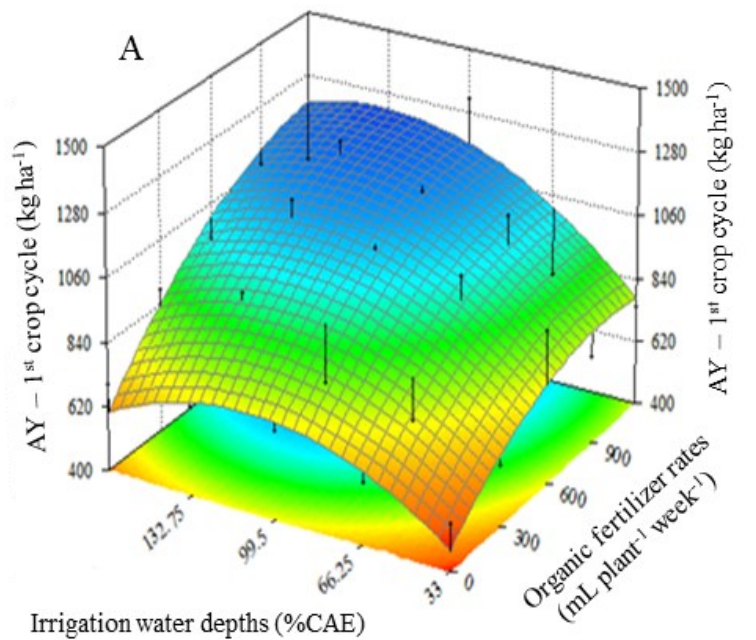

Irrigation water depths $(\% \mathrm{CAE})$

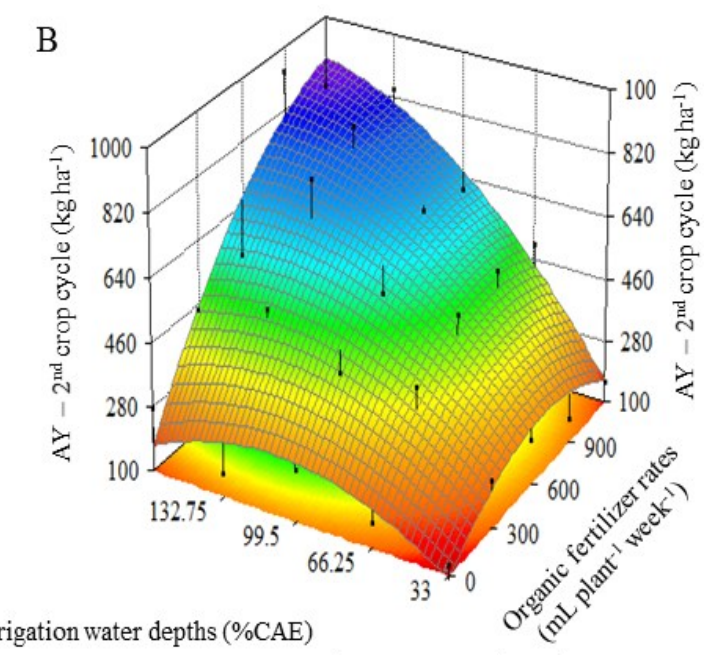

$$
\begin{aligned}
& \mathrm{AY}_{1}{ }^{\text {st }}{ }_{\text {crop cycle }}=198.6274+0.59353 * *(\mathrm{OFR})+9.6547 *(\mathrm{IWD})-0.000334(\mathrm{OFR})^{2}-0.04343 *(\mathrm{IWD})^{2}+0.00172 \\
& \text { (OFR)(IWD) } \quad \mathrm{R}^{2}=0.75 \\
& \mathrm{AY}_{2}{ }^{\text {nd }}{ }_{\text {crop cycle }}=-96.2571+0.37917 * *(\mathrm{OFR})+6.54073 *(\mathrm{IWD})-0.000373 *(\mathrm{OFR})^{2}-0.02965 *(\mathrm{IWD})^{2}+ \\
& 0.003976 *(\mathrm{OFR})(\mathrm{IWD}) \quad \mathrm{R}^{2}=0.91
\end{aligned}
$$

Figure 2. Response surface for achene yield (AY) in the first (A) and second (B) crop cycles of sunflower as a function of organic fertilizer rates (OFR) and irrigation water depths (IWD).

The increase in achene yield with increasing OFR can be due to the increased nutrient availability promoted by the organic matter. Cancellier et al. (2011) also observed the positive effect of this organic fertilizer, with increased efficiency over time, promoting adequate conditions for the development of crops. However, the subsequent application of the organic fertilizer (second cycle) may have caused a nutritional imbalance in the sunflower plants due to the high nutrient concentration in the pots, which reduced achene yield.

Under water deficit conditions, plants close their stomata to reduce transpiration and restrict water loss, causing a reduction in $\mathrm{CO}_{2}$ absorption, photosynthetic rates, photosynthate accumulation, and achene yield (TAIZ et al, 2013). This may explain the lower yields in treatments with the smaller IWD.

Achene yield is dependent on the amount of solar radiation in the achene filling stage, and rainfall in the flowering stage. These conditions occurred in the first cycle because of the highest rainfall depths in January and February (flowering), which altered the pre-established IWD, making them excessive.

Sunflower yield tends to respond to irrigation (SILVA et al., 2011). Araújo et al. (2012) found increases in sunflower yield with increasing IWD.

The mathematical model showed a better estimated water use efficiency (WUE) $\left(2.72 \mathrm{~kg} \mathrm{ha}^{-1}\right.$ $\mathrm{mm}^{-1}$ ) for the first cycle when using an OFR of $1,060.6 \mathrm{~mL} \mathrm{plant}^{-1}$ week $^{-1}$ and an IWD of $33 \%$ $(298.8 \mathrm{~mm})$ (Figure 3A). The best WUE in the second cycle would be $1.33 \mathrm{~kg} \mathrm{ha}^{-1} \mathrm{~mm}^{-1}$ when using an OFR of $845.8 \mathrm{~mL}$ plant $^{-1}$ week $^{-1}$ and an IWD of $70.9 \%(365.5 \mathrm{~mm})$ (Figure 3B). In the first cycle, the WUE increased with increasing OFR, with a sigmoidal fit for the IWD. In the second cycle, the greater curvature was found for the IWD factor, indicating higher influence of this factor on the WUE.

According to Campos, Chaves and Guerra (2015) sunflower crops have low WUE; each liter of water consumed produces less than $2 \mathrm{~g}$ of dry matter. However, this WUE increases considerably in water deficit conditions (CASTRO; FARIAS, 2005), which explains the results found in the present study. Duarte et al. (2012) observed reductions in WUE with application of high IWD.

The response of the achene oil content (AOC) to IWD in the first cycle was quadratic, with maximum AOC (48.7\%) when using an IWD of $82.87 \%$ of the CAE $(409.42 \mathrm{~mm})$. In the second cycle, the AOC varied between 42.3 and $48.3 \%$ and fitted to a linear model. 

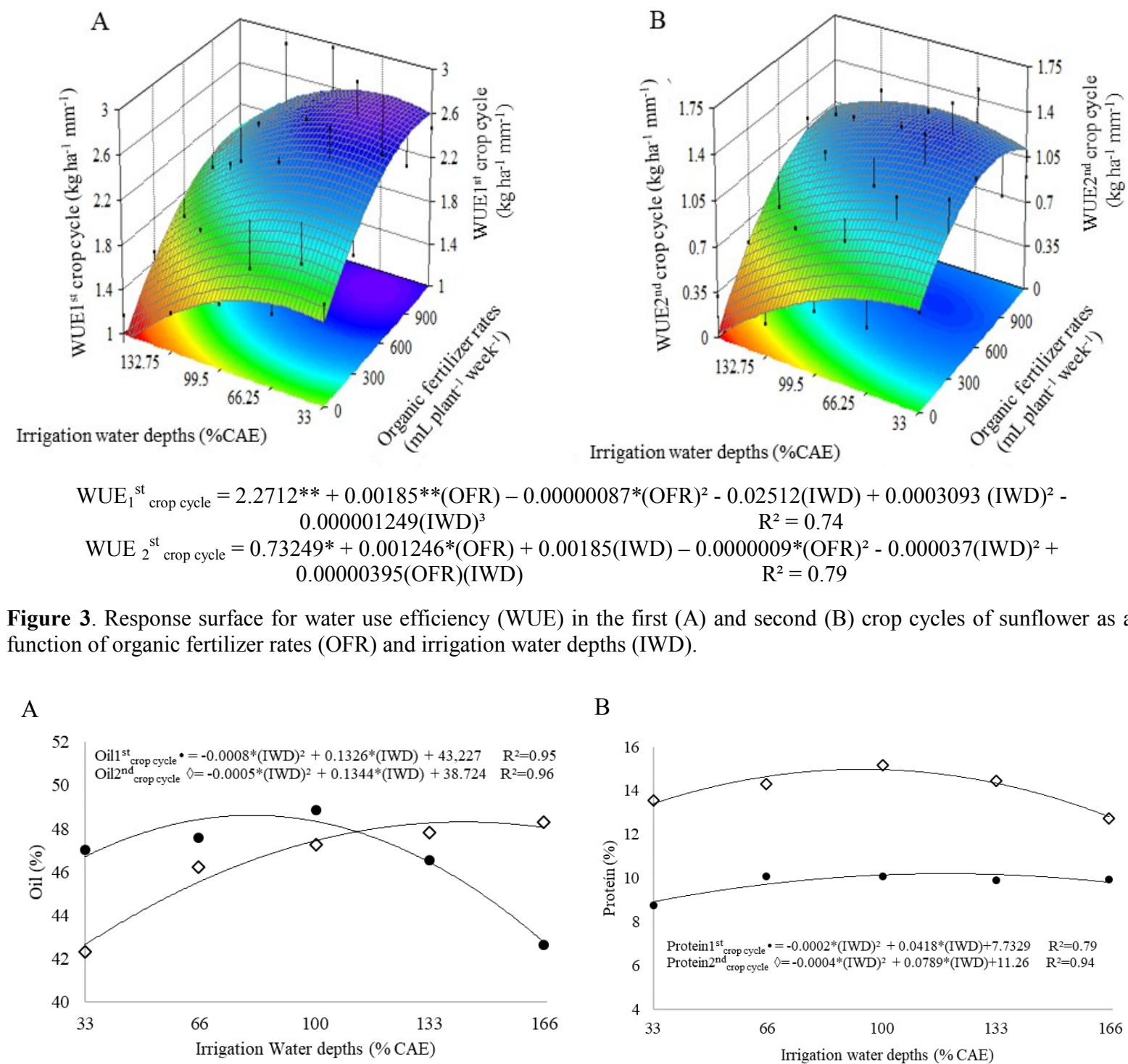

Irrigation water depths (\%CAE) 


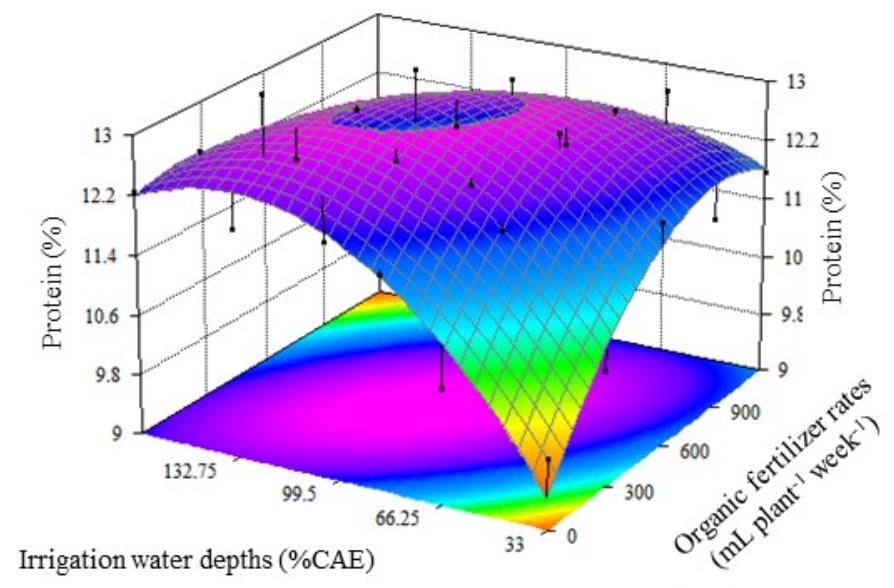

Protein $=7.1177414 *+0.0066747978 *(\mathrm{OFR})+0.080072998 *(\mathrm{IWD})-0.0000030110952 *(\mathrm{OFR})^{2}-$ $0.00029783236 *(\mathrm{IWD})^{2}-0.000032874533 *(\mathrm{OFR})(\mathrm{IWD}) \quad \mathrm{R}^{2}=0.84$

Figure 5. Response surface for achene protein content of sunflower plants as a function of organic fertilizer rates (OFR) and irrigation water depths (IWD) in two crop cycles.

The response of APC to OFR is explained by the increase in soil microbial activity due to the increased $\mathrm{N}$ availability with increasing OFR. Organic fertilization has several benefits; it increases soil $\mathrm{P}$ and $\mathrm{K}$ contents, dry matter yield, leaf $\mathrm{P}$, and crude protein (SILVA et al., 2012).

The treatments with the highest IWD increased APC (Figure 5). Contrastingly, Alahdadi and Oraki; Khajani (2011) found the lowest APC when the crops were fully irrigated.

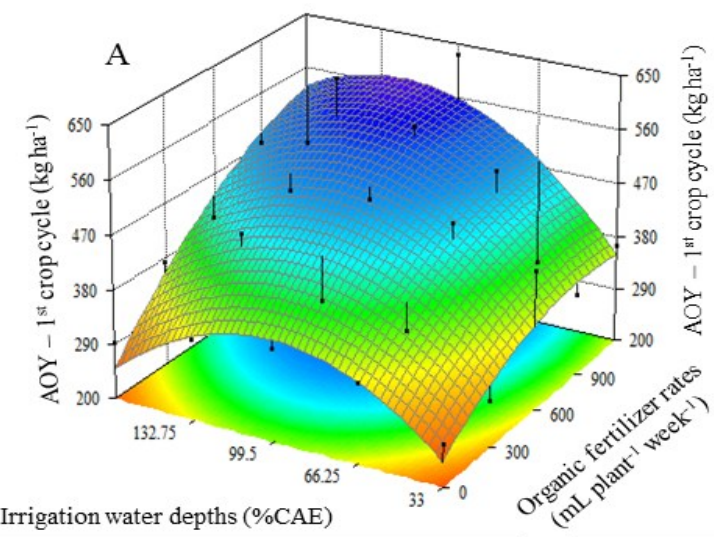

The achene oil yield (AOY) was higher in the first cycle, responding well to OFR, with maximum yield found using the highest rate. An OFR of 1,200 mL plant $^{-1}$ week $^{-1}$ with an IWD of $124.3 \%$ (501.13 $\mathrm{mm})$ would result in the highest AOY $(571.97 \mathrm{~kg} \mathrm{ha}$ ${ }^{1}$ ) in the first crop cycle (Figure 6A); and an OFR of $1,200 \mathrm{~mL}$ plant $^{-1}$ week $^{-1}$ with an IWD of $166 \%$ $(843.0 \mathrm{~mm})$ would result in the highest AOY $(411.58$ $\mathrm{kg} \mathrm{ha}^{-1}$ ) in the second cycle (Figure 6B), considering a plant density of 28,570 plants $\mathrm{ha}^{-1}$.

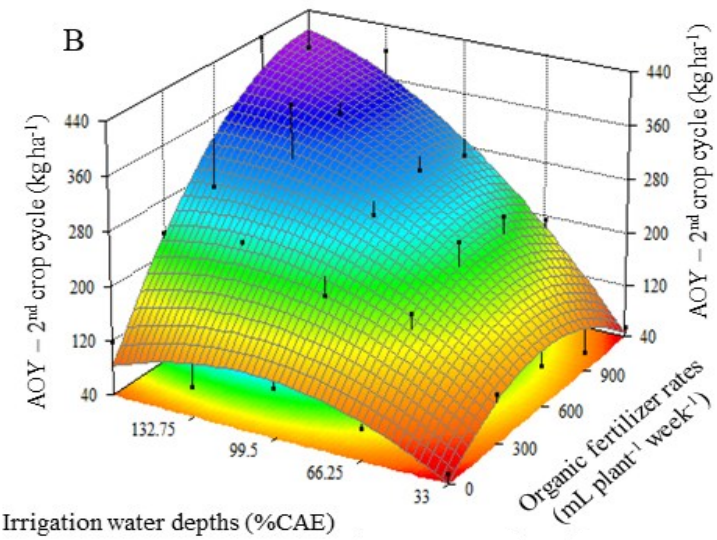

$$
\begin{gathered}
\mathrm{AOY}_{1}{ }^{\text {st }}{ }_{\text {crop cycle }}=90.599457+0.2075817(\mathrm{OFR})+5.4454729 * *(\mathrm{IWD})-0.00012828244(\mathrm{OFR})^{2}-0.026991742 * *(\mathrm{IWD})^{2} \\
+0.0010537077(\mathrm{OFR})(\mathrm{IWD}) \\
\begin{aligned}
& \mathrm{AOY}_{2}{ }^{\text {nd }}{ }_{\text {crop cycle }}=-46.058789+0.2067142 *(\mathrm{OFR})+3.0474695 *(\mathrm{IWD})-0.00022454241 *(\mathrm{OFR})^{2}-0.013664462 *(\mathrm{IWD})^{2} \\
&+0.0020260249 *(\mathrm{OFR})(\mathrm{IWD}) \mathrm{R}^{2}=0.92
\end{aligned}
\end{gathered}
$$

Figure 6. Response surface for achene oil yield (AOY) in the first (A) and second (B) crop cycles of sunflower as a function of organic fertilizer rates (OFR) and irrigation water depths (IWD).

AOC and AOY are commercially important parameters, and AOC is the most important for processing industries (SACHS et al., 2006). Therefore, it is important to invest in productivity and choose high-yield cultivars, such as the BRS324, which was developed for high oil yield, and reduced cycle. According to Alves et al. (2012), large grains have high weights, but low oil contents because they have a high hull volume and surface and low kernel volume.

Lobo et al. (2013) found a linear increase in AOY with increasing sludge rate, with maximum of 
1,597.6 $\mathrm{kg} \mathrm{ha}^{-1}$. Silva et al. (2011) also found increases in AOY (Catissol 01 cultivar) with increasing water depths, and maximum AOY of $1,851,55 \mathrm{~kg} \mathrm{ha}^{-1}$ with a water depth of $533.7 \mathrm{~mm}$ $(150 \% \mathrm{CAE})$, which is higher than the result found in the present study.

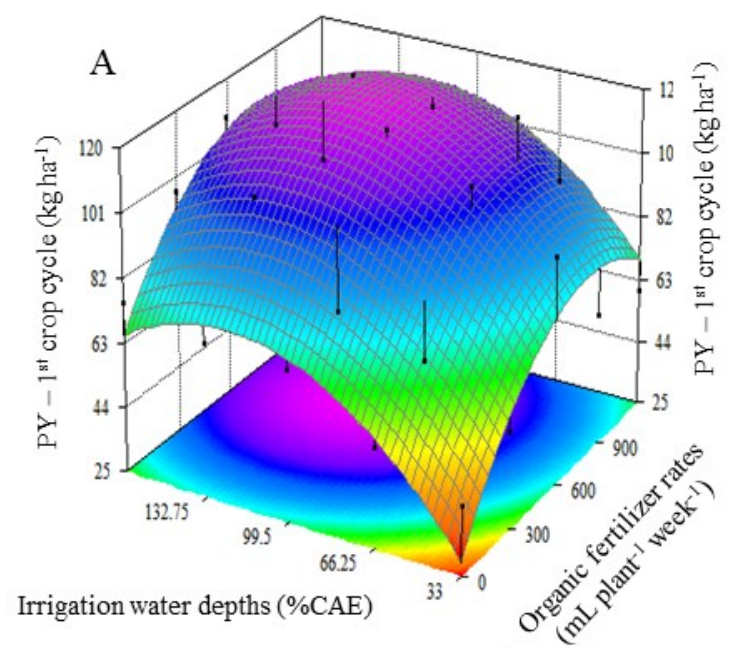

$$
\begin{aligned}
& \mathrm{PY}_{1}{ }^{\text {st }}{ }_{\text {crop cycle }}=-10.4878+0.1189165 *(\mathrm{OFR})+1.382628 *(\mathrm{IWD})-0.000069517 *(\mathrm{OFR})^{2}-0.00556083 *(\mathrm{IWD})^{2}- \\
& 0.0000720024(\mathrm{OFR})(\mathrm{IWD}) \quad \mathrm{R}^{2}=0.77 \\
& \mathrm{PY}_{2}{ }^{\text {st }} \text { crop cycle }=-38.5547 * * 0.085835 *(\mathrm{OFR})+1.45778 *(\mathrm{IWD})-0.0000669065 *(\mathrm{OFR})^{2}-0.00661532 *(\mathrm{IWD})^{2}+
\end{aligned}
$$

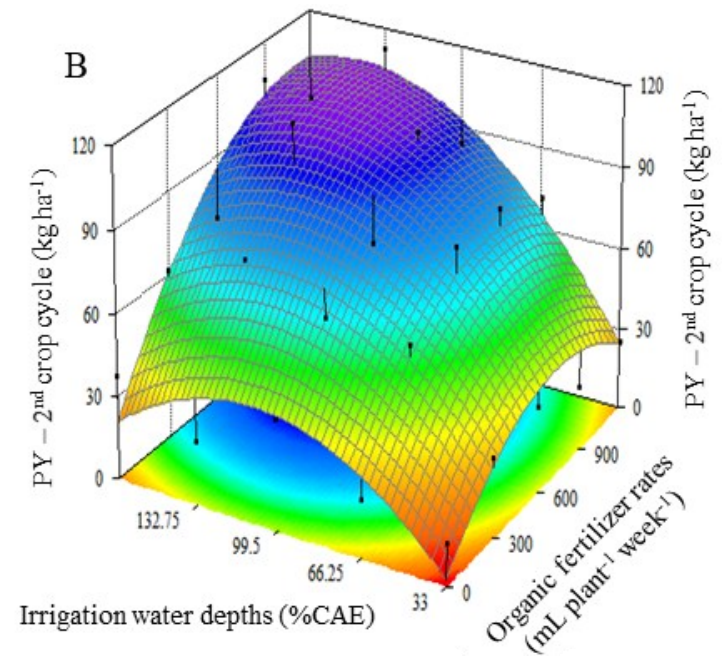

Figure 7. Response surface for achene protein yield (APY) in the first (A) and second (B) crop cycles of sunflower as a function of organic fertilizer rates (OFR) and irrigation water depths (IWD).

The BRS-324 cultivar was developed for high AOY; thus, it does not present a high protein productive potential, which explains the low APY found. AOY presents a negative correlation to APY; and achene yield presents an inverse correlation to APC, which was found in the present study.

According to Rangel et al. (2007), improving these characteristics through plant breeding is difficult, and increases in achene yield and resistance to diseases have receive greater attention than achene chemical composition; moreover, farmers sell their production by weight and not by achene protein or oil contents.

\section{CONCLUSIONS}

The highest estimated achene yields of sunflower plants of the BRS-324 cultivar in the first cycle was found with organic fertilizer rates (OFR) (goat manure) of $800 \mathrm{~mL}$ plant $^{-1}$ week $^{-1}$ and 1,200 $\mathrm{mL}$ plant $^{-1}$ week $^{-1}$, with irrigation water depths of $120 \%$ to $166 \%$ of the class A tank evaporation (CAE), presenting the highest yield of $1,220.78 \mathrm{~kg}$ $\mathrm{ha}^{-1}$.

The highest estimated achene yields in the second cycle was found with OFR of
1,000 mL plant ${ }^{-1}$ week $^{-1}$ and 1,200 mL plant ${ }^{-1}$ week $^{-1}$, with irrigation water depths of 140 to $166 \%$ of the CAE, presenting the highest yield of $882.07 \mathrm{~kg} \mathrm{ha}^{-1}$.

The mean achene oil content was $48 \%$, not differing between crop cycles. The highest oil content was found when using an IWD of $82.9 \%$ of the CAE (409.42 $\mathrm{mm})$ in the first cycle $(49 \%)$, and $166 \%(843.0 \mathrm{~mm})$ in the second cycle $(48.3 \%)$. The highest mean achene protein content was found in the second cycle $(14 \%)$, with a water depth of $100 \%$ of the CAE and an OFR of $536 \mathrm{~mL}_{\text {plant }}{ }^{-1}$ week $^{-1}$.

\section{REFERENCES}

ALAHDADI, I.; ORAKI, H.; KHAJANI, F. P. Effect of water stress on yield and yield components of sunflower hybrids. African Journal of Biotechnology, v. 10, n. 34, p. 6504-6509, 2011.

ALVES, F. V. et al. Composição química e qualidade fisiológica de sementes de girassol de plantas submetidas à competição intraespecífica. Revista Brasileira de Sementes, v. 34, n. 3, p. 457$465,2012$.

ARAÚJO, T. V. O. et al. Lâminas de irrigação e 
coberturas do solo na cultura do girassol, sob condições semiáridas. Revista Irriga, v. 17, n. 2, p. 126-136, 2012.

BRASIL. Ministério da Agricultura e Reforma Agrária. Secretaria Nacional de Defesa Agropecuária. Departamento Nacional de Defesa Vegetal. Coordenação de Laboratório Vegetal. Regras para análise de sementes. Brasília, DF, 1992. 365 p.

CAMPOS, V. B.; CHAVES, L. H. G.; GUERRA, H. O. C. Adubação com NPK e irrigação em Luvissolo: Comportamento vegetativo. Revista Ambiente e Água, v. 10, n. 1, p. 221-233, 2015.

CANCELLIER, L. L. et al. Adubação orgânica na linha de semeadura no desenvolvimento e produtividade do milho. Semina: Ciências Agrárias, v. 32, n. 2, p. 527-540, 2011.

CASTRO, C.; FARIAS, J. R. B. Ecofisiologia do girassol. In: LEITE, R. M. V. B. C.; BRIGHENTI, A. M.; CASTRO, C. (Eds.). Girassol no Brasil. Londrina: Embrapa Soja, 2005. cap. 9, p. 163-218.

CARVAlHO, C. G. P. et al. Cultivar de girassol BRS 324 - Variedade com alto teor de óleo e produtividade. 1. ed. Londrina: Embrapa Soja, 2013. 2 p. (Folder, n. 09).

DIAS, C. N. Cultivo do morango sob diferentes condições de ambientes e doses de biofertilizante na região do Maciço de Baturité, Ceará. 2014. 93 f. Dissertação (Mestrado em Engenharia Agrícola: Área de Concentração em Irrigação e Drenagem) Universidade Federal do Ceará, Fortaleza, 2014.

DUARTE, J. M. L. et al. Eficiência no uso da água na produção de óleo do girassol (Helianthus annuus L.), sob suspensão hídrica. Revista Brasileira de Agricultura Irrigada, v. 6, n. 3, p. 166-175, 2012.

EMPRESA BRASILEIRA DE PESQUISA AGROPECUÁRIA - EMBRAPA. DONAGENA, G. $\mathrm{K}$. et al. (Eds.). Manual de métodos de análises de solos. 2.ed. Rio de Janeiro, RJ: Embrapa Solos, 2011. 230 p.

FREIRE, J. L. O. et al. Necessidade hídrica do maracujazeiro-amarelo cultivado sob estresse salino, biofertilização e cobertura do solo. Revista Caatinga, v. 24, n. 1, p. 82-91, 2011.

LIMA, F. A. et al. Irrigação da cultura do gergelim em solo com biofertilizante bovino. Revista Brasileira de Agricultura Irrigada, v. 7, n. 2, p. 102-111, 2013.

LOBO, T. F. et al. Efeito do lodo de esgoto e do nitrogênio nos fatores produtivos do girassol. Revista Brasileira de Engenharia Agrícola e Ambiental, v. 17, n. 5, p. 504-509, 2013.

MAlavolta, E. et al. Adubos e Adubações. 1. ed. São Paulo, SP: Nobel, 2002. 200 p.

OLIVEIRA, A. P. et al. Rendimento de maxixe em solo arenoso em função de doses de esterco bovino e biofertilizante. Revista Brasileira de Engenharia Agrícola e Ambiental, v. 18, n. 11, p. 1130-1135, 2014.

RANGEL, M. A. S. et al. Efeitos da interação genótipos $\mathrm{x}$ ambientes no rendimento de grãos e nos teores de proteína de cultivares de soja. Revista Acta Scientiarum Agronomy, v. 29, n. 3, p. 351354, 2007.

SACHS, L. G. et al. Efeito de NPK na produtividade e componentes químicos do girassol. Revista Semina, v. 27, n. 4, p. 533-546, 2006.

SANTOS, M. J. et al. Seca, precipitação e captação de água de chuva no semiárido de Sergipe. Engenharia Ambiental, v. 6, n. 1, p. 55-73, 2009.

SILVA, D. J. et al. Análise de alimentos: métodos químicos e biológicos. 3.ed. Viçosa, MG: UFV, 2004. $235 \mathrm{p}$.

SILVA, A. R. A. et al. Desempenho de cultivares de girassol sob diferentes lâminas de irrigação no Vale do Curu, CE. Revista Ciência Agronômica, v. 42, n. 1, p. 57-64, 2011.

SILVA, J. A. S. et al. Rendimento do inhame adubado com esterco bovino e biofertilizante no solo e na folha. Revista Brasileira de Engenharia Agrícola e Ambiental, v. 16, n. 3, p. 253-257, 2012.

SIMÕES, W. L. et al. Aspectos morfofisiológicos do girassol irrigado por gotejamento no submédio são Francisco. Irriga, v. 1, n. 1, p. 66-77, 2016.

SOARES, S. R.; GALBIATTI, J. A. Efeito da aplicação de água residuária de suinocultura na Brachiaria brizantha 'Marandu'. Revista Colombiana de Ciencia Animal, v. 4, n. 1, p. 185 203, 2012.

SOUSA, G. G. et al. Fertirrigação com biofertilizante bovino: Efeitos no crescimento, trocas gasosas e na produtividade do pinhão-manso. Revista Brasileira de Ciências Agrárias, v. 8, n. 3, p. 503-509, 2013.

SOUSA, G. G. et al. Lâminas de irrigação para cultura do gergelim com biofertilizante bovino. Revista Magistra, v. 26, n. 3, p. 343-352, 2014. 
TAIZ, L. et al. Fisiologia vegetal. 5.ed. Porto Alegre, RS: Artmed, 2013. 954 p.

VIANA, T. V. A. et al. Lâminas de irrigação e coberturas do solo na cultura do girassol sob condições semiáridas. Irriga, v. 17, n. 2, p. 126-136, 2012. 